\title{
Association Between Serum Paraoxonase And Ceruloplasmin Oxidase In Iraqi Pregnants Women With And Without Complications
}

\author{
${ }^{1}$ Israa Ghassan , ${ }^{2,}$ Zaizafoon Nabeel \\ Al-Mustansiriyah University, College of Science, Department of Chemistry, Baghdad-Iraq
}

\begin{abstract}
The aim of this study is to assess the comparison of serum paraoxonase (PON), ceruloplasmin oxidase $(C P)$, alkaline phosphatase (ALP) activities, creatinine, calcium Ca, inorganic phosphate $(P)$, zinc $\mathrm{Zn}$, copper $\mathrm{Cu}$ and iron Fe levels. The study was performed on 88 pregnants women divided in the following groups: missed abortion $(M A)(n=25)$, ectopic $(E P)(n=17)$, molar $(M P)(n=21)$ and normal pregnant women $(n=25)$ as control. PON decreased in all studied groups $(p \leq 0.05)$, while $C p, A L P$ activity was decreased only in $E P$ and MP groups $(p \leq 0.05)$.Creatinine level was increased in MP groups $(p \leq 0.05)$. Non-significant differences in Zn levels in all patients groups. The P level was decreased $(p \leq 0.05)$ in MA group, while Ca decreased $(p \leq 0.05)$ in all studied groups. $C u$ levels were elevated $(p \leq 0.05)$ in EP and MP groups. Fe concentrations were reduced $(p \leq 0.05)$ in $E P$ and MP groups. Paroxonase correlated negatively with $(C P(r=$ - 0.425, $p=0.043)$ in EP, and with PON \& $\mathrm{Cu}(r=-0.53, p=0.013)$ in MP and and with creatinine $(r=-$ $0.463, p=0.020)$ in MA patients). Paraoxonase also positively correlated with $C P(r=0.587, p=0.005)$ in $M P$ and with $C u(r=0.535, p=0.027)$ in EP patients. The study conclusions that PON and CP as antioxidants may play role in monitoring the pregnancy complications.
\end{abstract}

Key words: paraoxonase, ceruloplasmin oxidase; ectopic; mole and miscarriage .

\section{Introduction}

Pregnancy is a stressful condition in which many physiological and metabolic functions are altered to considerable extent ${ }^{[1]}$. While most pregnancies result in the birth of a healthy baby. Occasionally, some pregnancy goes wrong from the beginning. The symptoms and problems that are associated with pregnancy are known as complications of pregnancy. There both routine problems and serious and even potentially fatal problems. The routine problems are normal complications and pose no significant danger on either the mother or the fetus. Serious problems can cause both maternal and fetal death if untreated ${ }^{[2]}$. The most common complication of early pregnancy is missed abortion, mole and ectopic pregnancy. Miscarriage or spontaneous abortion is the spontaneous end of a pregnancy at a stage where the embryo or fetus is incapable of surviving independently, generally defined in human at prior to 20 weeks of gestation ${ }^{[3]}$. It can occur for many reasons, not all of which can be identified. Some of these causes include genetic, uterine or hormonal abnormalities, reproductive tract infections and tissue rejection ${ }^{[4]}$. Ectopic pregnancy is an abnormal pregnancy that occurs outside the womb. The fetus cannot survive and often does not develop at all ${ }^{[5]}$. The common site for the ectopic pregnancy is within one of the tubes through which the egg passes from the ovary to the uterus or in the ovary, stomach area or cervix ${ }^{[6]}$. The main cause is a condition that blocks or slows the movement of fertilized egg through the fallopian tube to the uterus, this may be caused by a physical blockage in the tube by hormonal factors and by others such as smoking ${ }^{[7]}$. A hydatidiform mole is a rare mass or growth that forms inside the uterus at the beginning of pregnancy ${ }^{[8]}$. It is resulted from over production of the tissue that is supposed to develop in to the placenta. The placenta normally feeds the fetus during pregnancy. In this case, the tissues develop into an abnormal growth, called a mass. There are two types: partial and complete mole pregnancy, both forms are due to problems during fertilization. The exact causes of fertilization problems are unknown. However, a diet low in protein animal fat and vitamin A may play a role ${ }^{[9]}$.

An imbalance between the lipid peroxidation process and antioxidative protection is associated with pathophysiology of pregnancy complications ${ }^{[10]}$. Human serum paraoxonase (PON) is an enzyme bound to high density lipoprotein (HDL)that hydrolyses oxidized phospholipids and inhibits low density lipoprotein (LDL) oxidation .It is the major determination of antioxidant action of HDL. Paraoxonase, aryldialkylphosphatase (EC 3.1.8.1) is a calcium dependent ester hydrolase that catalyzes the hydrolysis of some 
xenobiotics, such as organophosphorous insecticides, unsaturated aliphatic esters, aromatic carboxyl esters and possibly carbamates ${ }^{[11,12]}$. There are three known genotypic forms of PON which are coded by a set of genes PON1,PON2 and PON3, respectively and are located on long arm of chromosome 7. PON1 is synthesized in liver and transported in plasma by binding to HDL. PON2 is expressed intracellular protein ${ }^{[13]}$. PON1, a 44-kD with 354 amino acids ${ }^{[13,14]}$. Paraoxonase was so called because paraoxon, the active metabolite of the organophosphorous compounds insecticide parathion, is the commonly used subtrate to measure its enzyme activity ${ }^{[15]}$. Other nomenclatures include parathion-hydrolase and aryldialkyl phosphatase because it catalyzes the hydrolysis of an aryldiakylphosphate (likeanparaoxon, O, O-diethyl p-nitrophenyl phosphate) into dialkyl phosphate (p-nitro phenol) and an aryl alcohol (diethyl phosphoric acid) ${ }^{[16]}$. There are several studies that investigated paraoxonase activity in pregnancy with and without complications and found that serum PON was reduced or there were not any significant changes. Pregnancy is associated with increased demand of all micronutrients like iron, copper, zinc, vitamin B12, folic and ascorbic acids ${ }^{[17]}$. The deficiency of these nutrients could affect pregnancy, delivery and outcome of pregnancy. Vitamins and minerals are collectively referred to as micronutrients and have important influence on the health of pregnant women and growing fetus ${ }^{[18]}$. Conditions not directly related to copper nutriture, such as pregnancy, infections and inflammations which increase serum copper concentration even during copper deprivation may be expected to conceal change in copper status. It has been suggested that specific enzymatic activity of ceruloplasmin may be sensitive indicator of copper status and is not affected by factors such as hormones or sex ${ }^{[19]}$. Ceruloplasmin oxidase is an enzyme (EC 1.16.3.1) synthesized in the liver containing 6 atoms of copper in its structure. Ceruloplasmin carries about $70 \%$ of total copper in human plasma while albumin carries about $15 \%$. The rest is accounted for by macroglobulins. Ceruloplasmin exhibits a copper-dependent oxidase activity, which is associated with possible oxidation of $\mathrm{Fe}^{+2}$ (ferrous iron) in to $\mathrm{Fe}^{+3}$ (ferric iron), therefore assisting in its transport in the plasma in association with transferring, which can carry iron only in the ferric state.The molecular weight of human ceruloplasmin is reported to be $151 \mathrm{KDa}^{[20]}$. The specific oxidase activity of ceruloplasmin was studied in plasma and serum of pregnant women with and without complications. The specific oxidase activity decreased in all pregnant with pathology, this decrease were thought to offer the cell protection from damage caused by the increased oxidative stress associated with pregnancy ${ }^{[21]}$.This paper aimed to assess the levels and relationship between PON, CP, ALP and some biochemical parameters in Iraqi women with and without pregnant complications .

\section{Materials And Methods}

The study populations consisted of about 88 pregnants women with age ranged between (14-35) years in the first trimester of gestation, who visited medical city, Al-Yarmook and Fatima AL-Zahraa hospitals, and clinically diagnosed patients by: Twenty five pregnancies $(n=25)$ with no any complications were included as control. The rest 63 pregnant women with complications were divided into: missed abortion (MA) $(n=25)$, ectopic pregnant (EP) $(n=17)$ and molar pregnant (MP) $(n=21)$. Informed consent was taken from the subjects prior to the study. Selection of serum samples was based on $\beta$-HCG levels more than 1000 munits $/ \mathrm{ml}$ and ultrasound findings of NP, MA, EP or MP. None of the selected women suffered from any other type of disease. They were compared for gestation age, $\mathrm{Hb}$, laboratory assays, $\mathrm{BMI}\left(\mathrm{Kg} / \mathrm{M}^{2}\right)$, maternal age and number of children, table(1). The process of collecting specimens by withdraw about $10 \mathrm{ml}$ of vinous blood using plastic disposable syringes, and then left for 20 minutes at room temperature. After coagulation, sera were separated by centrifugation at $1500 \mathrm{xg}$ for 10 minutes. Hemolyzed samples were discarded and sera were stored and frozen about $-20^{\circ} \mathrm{C}$ until analysis. Serum paraoxonase activity was determined according to the method described by Mueller et al. ${ }^{[22]}$ by measuring the rate of hydrolysis of paraoxon (supplied by Sigma-Aldrich Co. (St. houis, Mo)), by monitoring the increase of absorbance at $405 \mathrm{~nm}$ at $37^{\circ} \mathrm{C}$. PON activity was expressed as nmole $/ \mathrm{min} / \mathrm{L}$ serum. The enzymatic assay of ceruloplasmin oxidase activity was accomplished using the modified Rice method and p-phenylene diamine-2HCL as a substrate ${ }^{[23]}$. The CP activity was expressed in term of (U/L) . The levels of alkaline phosphatase (ALP), creatinine(Cr), Calcium (Ca), inorganic phosphors (P) were measured using commercially available assay kits (Biomaghreb, Al-Maghreb). Serum zinc, copper and iron concentrations were determined by using flameless atomic absorption.Statistics: statistical analysis was done using SPSS version 10.0 and values are expressed as mean $\pm \mathrm{SD}$ and $\mathrm{P}$ values were tabulated. Statistical significance was defined as $\mathrm{P}<0.05$. The comparison of parameters was performed using student $\mathrm{t}$-test and correlation analysis was performed using pearsons correlation test.

\section{Results}

Demographic data of the studied groups were summarized in table1. There were no significant differences in age, BMI and number of children. However, there were a significant differences $(p<0.05)$ between all studied groups and normal group in regard to $\mathrm{Hb}$, gestation age respectively. The mean values of all parameters in the studied groups are presented at table 2 . The results indicated that there were statistically 
significant decreases in serum paraoxonase activity in cases of missed, ectopic and molar pregnancy when compared to control group. The lowest paraoxonase activity was noticed in ectopic pregnancy. Ceruloplasmin activity decreases significantly in cases of ectopic and molar compared to control . Lowest CP was noticed in moalr group. Alkalin phosphatase activity was decreasing significantly in women with ectopic and mole pregnancy and non significant difference in miscarriage compared to control. The Creatinine levels were significantly higher in women with mole than control group; women with ectopic pregnancy did not show any significant differences.Significant decreases in calcium levels were present in all patients groups compared with control. Inorganic phosphate levels were decreased none significantly in women with ectopic and significantly in molar group, while miscarriage group did not show any significant changes. In addition, serum trace elements like ( $\mathrm{Zn}, \mathrm{Cu}, \mathrm{Fe}$ ) were cleared the following results: Serum Zinc concentrations did not show any differences in all groups, copper concentrations were significantly elevated in ectopic and molar groups and finally iron concentrations were significantly reduced in ectopic and molar groups compared to control Pearson product moment correlation analysis was carried out to determine the relationship between paraxonase and the other studied parameters. There was a negative correlation between PON \& CP $(\mathrm{r}=-0.425, \mathrm{p}=0.043)$ in EP , between PON \& Cu $(\mathrm{r}=-0.53, \mathrm{p}=0.013)$ in MP and between PON \& creatinine $(\mathrm{r}=-0.463, \mathrm{p}=0.020)$ in MA patients. Paraoxonase also positively correlated with $\mathrm{CP}(\mathrm{r}=0.587, \mathrm{p}=0.005)$ in $\mathrm{MP}$ and with $\mathrm{Cu}(\mathrm{r}=$ $0.535, \mathrm{p}=0.027$ ) in EP patients as cleared in table 3 .

\section{Discussion}

In the present study, results indicated that serum PON activity was lower significantly in all patients groups compared to control, while CP activity was lower significantly only in molar and ectopic groups only . $\mathrm{PON}_{1}$ is antioxidant enzyme located in HDL that protect vascular tissue from oxidative damage by protects low density lipoprotein and HDL from oxidation and responsible of the antioxidant activity of HDL [24]. This protection is probably related to the ability of paraoxonase to hydrolyze some oxidized phospholipids and/or cholesteryl linoleate hydroperoxides. Serum PON activity was found to be reduced in a number of pathological conditions including myocardial infarction, diabetes and pregnancy failure ${ }^{[25]}$. Ceruloplasmin oxidase was higher in normal pregnancies in comparison to other groups with pregnancy complications. These results of PON and CP were thought to offer the cell protection from the damage caused by the increased oxidative stress associated with pregnancy. Ceruloplasmin (ferroxidase activity), like PON known as oxidant defense enzyme and decreases significantly in pregnant women with complications ${ }^{(41)}$. Although pregnancy accelerates the rate of CP protein synthesis and release with an increase of serum copper, our study showed reduced of CP activity and elevated of copper concentration. The decreases in specific CP in circulating would be an indicator of degree of depletion of the mothers copper deposits in order to deal with the fetus need, these finding was in agreement with previous studies by Louro et al. ${ }^{[19]}$ and Savila et al. ${ }^{[17]}$.Pregnancy is a physiological state associated with enhanced oxidative stress related to high metabolic turnover and elevated tissue oxygen requirements. Loss of antioxidant defenses has been shown to be associated with pregnancy failure. Early pregnancy failure is a common pregnancy complication with $15 \%$ to $20 \%$ of clinically recognized pregnancies ending in miscarriage.

Ayse et. al. indicated that in erythrocyte oxidant-antioxidant defense system may be impaired in miscarriage ${ }^{[26]}$. Biochemical markers of reactive oxygen species-induced membrane damage, such as lipid peroxidation products reach high levels immediately before abortion ${ }^{[27]}$. It has been suggested that an oxidant/antioxidant imbalance is associated with pregnancy failure ${ }^{[28]}$. Increased oxidative stress may alter placental vasculature, the prostacyclin-throuboxane balance and culminating in abortion ${ }^{[29]}$. The decrease in $\mathrm{PON}_{1}$ activity may play an important role in pathogenesis of early pregnancy failure through increased susceptibility to lipid peroxidation ${ }^{[30]}$. Mugeet. al. ${ }^{[31]}$ concluded that patient with complete hydatidiform mole are exposed to oxidative stress, which may have a role in the pathogenesis of the disease. According to the literatures, there are many studies that investigated serum PON enzyme activity in normal and preeclampstic pregnancy but this is the first paper reporting on the $\mathrm{PON}_{1}$ activity in ectopic and molar pregnant women. Roy et. al. ${ }^{[32]}$, reported that serum PON activity was higher at 28 to 32 week of normal pregnancy compared with the postnatal values and those of the non-pregnant control. Ferreet. al. ${ }^{[33]}$, investigated longitudinal changes in serum $\mathrm{PON}_{1}$ activity and found that serum enzyme was reduced at 32 weeks of pregnancy and at labor. The results in this paper were in agreement with Meera et. al. ${ }^{[34]}$, who reported oxidative stress and decreased PON activity in preeclampsia, and Aksoyet. al. ${ }^{[35]}$ in same line, it has be shown that serum paraoxonase and arylestrase activities decrease in preeclampsia, and this sitation may be associated with increased LOOH in these patients.Lower PON activity investigated also in normal pregnancy by Emre et. al. ${ }^{[36]}$ and in pregnancy failure by Harunet. al. ${ }^{[30]}$ and in anemia during pregnancy by Hakun et. al. ${ }^{[37]}$. On other hand Yaghmaei et. al. ${ }^{[38]}$ and Baker et. al. ${ }^{[39]}$ studies showed an increased in PON activity in preeclampsia patients and consider $\mathrm{PON}_{1}$ allele $192 \mathrm{R}$ is a risk factor for preeclampsia. Ebruet. et. al. ${ }^{[40]}$, found that no association between serum 
PON and hydratidiform mole. Clinically extremely elevated levels of ALP enzyme detected in the $3^{\text {rd }}$ trimester of gestation. The authors point out the potential relationship between elevated placental isoenzyme of ALP levels and placental insufficiency and the onset of preterm delivery ${ }^{[42]}$.Laboratory tests showed reduced values of ALP enzyme in both ectopic and molar groups, these may be due to abnormal saturation of placenta and fetus in both diseases and the over production of tissue that is supposed to develop into the placenta. The placenta normally feeds a fetus during pregnancy. Our finding was agreed with Lazebniket. al. ${ }^{[43]}$, who showed that ALP level, reduces in plasma of women with pregnancy complications. Creatinine serum levels were increased significantly in molar group, while the studies reported slightly lower of creatinine level during normal pregnancy. Maha et. al. ${ }^{[44]}$ evaluated the role of maternal serum creatine kinase in ectopic pregnancy and found that there was an increase in the serum creatine kinase levels accompanying muscular damage in ectopic pregnancy probably antedates tubal rupture. Significant decreases were found in concentrations of calcium in all groups, but there was significant decreased in $\mathrm{PO}_{4}^{-3}$ level in molar and non-significant changed in ectopic and miscarriage groups. There are several characteristic changes in maternal serum chemistries and calcotropic hormones during pregnancy, which can easily be mistaken as indicating the presence of disorder of calcium, $\mathrm{PO}_{4}^{-3}$ and bone metabolism ${ }^{[45]}$. Nutritional deficiencies are common during pregnancy; trace elements have been documented to play an important role in determining fetal outcome. This study indicated that the levels of $\mathrm{Fe}$ and $\mathrm{Cu}$ are lower in ectopic and molar group, when compared to control group, this could be a result of competitive inhibition in the absorption of trace elements in intestine or an effect of hormonal changes (insulin, estrogen) during pregnancy complications. There were many studies reported that no statistically significant variation were found in serum zinc concentration ${ }^{[17]}$. Jamesons ${ }^{[46]}$ and Senguptaet. al. ${ }^{[47]}$, reported decrease in $\mathrm{Zn}, \mathrm{Cu}$ and $\mathrm{Fe}$ levels in normal and abnormal pregnant women. Further studies are required to substantiate the postulated correlation between the lower paraoxonase, ceruloplasmin oxidase activities and pathophysiology of miscarriage, molar and ectopic pregnancy.

\section{REFERENCES}

[1] Saladin, Kenneth S., "Anatomy and Physiology: the Unity of Form and Function", $6^{\text {th }}$ Ed., New York NY, McGraw-Hill, (2012).

[2] Stuart I. F., "Human Physiology", $10^{\text {th }}$ Ed., Mc Graw Hill Medical, China, 2008, 20, 707-708.

[3] John O., Joseph I., Lisa M., et. al., "Williams Gynecology", $1^{\text {st }}$ Ed., Mc Graw Hill Medical, China, 2008, 6:142-144.

[4] Kaufman, Matthew H., Latha S. and Feig R., "First Aid for the Absotetrics and Gynecology Clerkship", New York, McGraw-Hill, Medical Pub. Division, 2007, 138.

[5] Houry E., Salhi B. A., "A cute Complications of Pregnancy", in Marx Ja Ed., Rosens Emergency Medicine: Concepts and Clinical Practice $7^{\text {th }}$ Ed., Philadelphia, Pa: Mosby Elsevier, 2009, Chap 176.

[6] Lobo R. A., "Ectopic Pregnancy: Etiology, Pathology, Diagnosis, Management and Fertility Prognosis", In Katz V. L., Lentz G. M., Lobo R. A., Gershenson D. M., Eds Comprehensive Gynecology $5^{\text {th }}$ Ed., Philadelphia, Mosby Elsevier, 2007, Chap. 17.

[7] Basnhart K. T., "Ectopic Pregnancy", N. Engle. J. Med., 2009, 361:379-387, Pub. Med.

[8] Copleand L. J. and London M. B., "Malignant Diseases and Pregnancy", In. Gabbes S. G., Niebyl J. R., Simpson J. L., Eds. Obstetrics Normal and Problem Pregnancy, $5^{\text {th }}$ Ed., Philadelphia, Pa: Elsevier Churchill Livingsline, 2007, Chap. 45.

[9] Goldstein D. P. and Berkowitz R. S., "Gestational Trophoblastic Disease" in: Abeloff M. D., Armitage J. O., Niederhuber J. E., Kastan M. B., MCKenna W. G., Eds. Abeloff's Clinical Genecology $4^{\text {th }}$ Ed., Philadelphia, Pa, Elsevier Churchill Livingstone, 2008 , Chap. 94.

[10] Ray J. G., Diamond P., Singh G. and Bell C. M., "Brief Overview of Maternal Triglycevides as a Risk Factor for Preeclampsia", BJOB, 2006, 21(1), :104-108.

[11] La Du B. N., "Structural and Functional Diversity of Paraoxonases", Nat. Med., 1996, 2:1186-7.

[12] Watson A. D., Berliner J. A., Hama S. Y., LaDu B. N. and Fogelman A. M., " Protective Effect of High-Density Lipoprotein Associated Paraoxonase Inhibition of the Biological Activity of Minimally Oxidized of LDL", J. Clin. Invest., 1995, 96, 2882.

[13] Getz G. S. and Reardon C. A., "PON, A Cardio Protective Enzyme", Continuing Issue, Curr. Opin. Lipidd, 2004, 15:261-6.

[14] Furlong C. E., Richter R. J., Min W. K. and Kim J. Q., "Genetic Variations of the Paraoxonase Gene in Patients with Coronary Artery Disease", Clin. Biochem, 2001, 34, 475-481.

[15] Gan K. N., Smolen A., Ekerson H. W. and LaDu B. N., "Purification of Human Serum Paraoxonase/Arylesterase. Evidence for One Esterase Catalyzing Both Activities", Drug MetabDispas, 1991, 19, 100.

[16] Machness M. I., Mackness B., Dwringtoon P. N., Connelly P. W. and Hegle, "Paraoxonase: Biochemistry, Genetics and Relationship to Plasma Lipoproteins", Curr. OpinLipidol, 1996, 7, 69.

[17] Savitu R., Ashish G., Hitende S., et. al., "Comparative Study of Trace Elements and Serum Cerubplasma Level in Normal and PreEclamptic Pregnancies with Their Cord Blood", Bio Med. Res., 2011, 22(2), :207-210.

[18] Black R. E., "Micronutrients in Pregnancy", Br. J. Nut., 2001, 85 :193-197.

[19] Louro M. O., Locho J. A., Tutor J. C., "Assessment of Copper Status in Pregnancy by Means of Determining the Specific Oxidase Activity", Clin. Chim. Acta., 2001, 312(1-2):123-7.

[20] Vilit O., Selek S., Bulut M., et. al., "High Ceruloplasmia Levels are Associated with Obsessive Compulsive Disorder", Behav. Brain. Fact, 2008, $4: 52$

[21] Krainova T. A., Morozova I. V., Efremova L. M., Et. al., "Assessment of the Specific Oxidase Activity in Pregnancy", Bio. Med. Khim., 2005, 51(6) :673-8.

[22] Mueller R. F., Hormung S., Furlong C. E.,et. al., "Plasma PON Polymorphism: A New Enzyme Assay, Population, Family, Biochemical and Linkage Studies", Am. J. Hum. Genet, 1983, 35, :393-408.

[23] Erel O., "Automated Measurement of Serum Peroxides Activity", Clin. Chem., 1998, 44:2313-2319.

[24] Watson A. D., Berliner J. A., Hama S. Y. and et. al., "Protective Effect of High Density Lipoprotein Associated Paraoxonase", J. Clin. Invest, 1995, 96, :2882-91.

[25] Aviram M., Rosenblat M., Bisgaier C. L., Newton R. S. and et. al., "Paraoxonase Inhibits HDL Oxidation and Preserves its Function", J. Clin. Invest., 1988, 101, :1581-90. 
[26] Aksoy A. N., Aksoy H., Ozturk N. and Bulut C., "Erythrocyte TAO and TBARS Levels in Patients Who Suffered Missed Miscarriage", Turk. J. Med., Scie., 2009, 39(6), :881-885.

[27] Sane A. S., Chokshi S. A., Mishra V. V. and et. al., "Serum Lipoperoxides in Induced and Spontaneous Abortions", Gynecol. Obstet. Invest., 1991, 31, :172-5.

[28] Lagod L., Paszkowski T., Sikorski R. and et. al., "The Antioxidant-Prooxidant Balance in Pregnancy Complicated by Spontaneous Abortion", Ginekol Pol, 2001, 72, :1073-8.

[29] Wang Y. P., Walsh S. W., Guo J. D. and et. al., "Maternal Levels of Prostacyclin, Thromboxane, Vitamine E and Lipid Peroxides Throughout Normal Pregnancy", Am. J. Obstet. Gynecol., 1991, 165, :1690-4.

[30] Harun T., Hakan C. and et. al., "Assessment of Serum Paraoxonase and Arylestrase Activities in Early Pregnancy Failure", Swiss Med. Weekly, 2009, 139(5-6), :76-81.

[31] Muge H., Mebmet H. and Ozcan E., "Increased Oxidative Stress in Patients with Hydafidiform Mole", Swiss Med. Weekly, 2003, $133,: 563-566$.

[32] Roy A. C., Loke D. F., Saha N. and et. al., "Interrelationship of Serum Paraoxznase, Serum Lipids and Apolipoproteins in Normal Pregnancy", Gynecol. Abstet. Invest., 1994, 38, :10-13.

[33] Ferre N., Comps J., Fernandez J. and et. al., "Longitudinal Changes in Serum PON 1 Activity throughout Normal Pregnancy", Clin. Chem. Lab. Med., 2006, 44, :880-882.

[34] Mecra K. S., Maitra S. and Hemalatha R., "Increased Level of Lipid Peroxidation in Preelamptic Pregnancy, a Relationship with PON $_{1}$ Activity", Biomedical Res., 2010, 21(4), 393-396.

[35] Aksoy A. N., Ozturk N., Aksoy H. and Akiy F., "PON ${ }_{1}$ and Arylestease Activities in Patients with Preeclampsia", Eurasian J. Med., 2008, (40): :1.

[36] Emre S. and Zehra S., "Serum PON and Arylestrase Activities throughout the Normal Pregnancy", Nobel Med., 2011, 7(1), :49-55.

[37] Hakan C., Harun T., Mehmet V., Alysun C., Abdullah T. and Hakim C., "Serum PON and Arylesterase Activities in Iron Deficiency Anemia During Pregnancy", Turk J. Med. Sci., 2011, 41(2), :185-191.

[38] Yaghmaei M., Hashemi M., Azarian A., Moazeni A., Mokhtari M. and et. al., "Association of L55M and Q192 R Polymorphisms of PON", Arch. Med. Res., 2011, 42(4) :324-8.

[39] Baker A. M., Klein R. L., Haeri S. and et. al., "Association of Midgestational PON 1 ", Am. J. Perinatol, 2010, 27(3), :205-10.

[40] Ebru O., Ozcan B., Ebru D., Mete G. and et. al., No Association between Serum PON, Arylesterase and Hydidiform Mole", Int. J. Gynecol. Cancer., 2011, 21(1), :149-52.

[41] Shakow S., Abbasali Z., Rashtchi Z., "Serum Level and Antioxidant Activity of Ceruloplasmia in Preeclompsia", Pakistan J. of Biol. Science, 2010, 13:621-627.

[42] Feriance V. and Linhartova L., "Extreme Elevation of Placental ALP", Neuro-Endocrinol. Lett., 2011, 32(2), :154-7.

[43] Lazebnik N., Kuhnert B., Kuhnert P. and Thompson K., "ALP and Zinc Status in Pregnancy Complications", Am. J. Obstet. Gynecol, 1988, 158(1), :161-6.

[44] Maha M. and Abdul Wahab R., "Maternal Serum Creatinkinase O Single Serum Progesterone Measurement as Predictors of Ectopic Pregnancy", Iraqi Med. J., 2006, 52(2), :94-99.

[45] Women American J. Obst. Gyna., 2006, 194, :639-49.

[46] Jameson S., "Zinc and Copper in Pregnancy and its Complications", Acta. Med. $2^{\text {nd }}$ Suppl., 1976, 593, :5-20.

[47] Sengupta S., Bhaskar M. and Haq I., "A Study of Micronutrient Status in Pregnancy", Indian J. Med. Assoc., 2010, 108(12), :81722 .

Table 1: Demographic Parameters in the studied groups

\begin{tabular}{|ccccc|}
\hline Parameters & Normal Pregnancy & Missed Abortion & $\begin{array}{c}\text { Ectopic } \\
\text { Pregnancy }\end{array}$ & Molar Pregnancy \\
Maternal Age & $25.16 \pm 5.97$ & $26.68 \pm 7.54$ & $26.41 \pm 6.99$ & $26.14 \pm 8.19$ \\
$\mathrm{Hb}(\mathrm{g} / \mathrm{dL})$ & $10.76 \pm 1.47$ & $11.817 \pm 1.59 *$ & $9.98 \pm 0.72 *$ & $9.90 \pm 1.54 *$ \\
$\mathrm{BMI}\left(\mathrm{Kg} / \mathrm{M}^{2}\right)$ & $26.51 \pm 4.97$ & $25.61 \pm 4.70$ & $26.36 \pm 2.37$ & $26.30 \pm 4.24$ \\
Number of & $1.72 \pm 1.86$ & $2.64 \pm 2.41$ & $1.41 \pm 1.27$ & $2.00 \pm 1.54$ \\
$\begin{array}{c}\text { Children } \\
\text { Gestation Age } \\
\text { (Months) }\end{array}$ & $4.88 \pm 0.88$ & $3.04 \pm 1.54 *$ & $1.94 \pm 0.24 *$ & $1.62 \pm 0.49 *$ \\
\hline \multicolumn{4}{r}{} \\
\hline
\end{tabular}

Table 2: Biochemical parameters levels in the studied groups. (Mean \pm SD)

\begin{tabular}{|c|c|c|c|c|c|c|c|c|c|}
\hline Parameters & $\mathbf{P O N}_{1}$ & $\mathbf{C P}$ & ALP & Cre. & $\mathbf{C a}$ & $\mathrm{PO}_{4}{ }^{-3}$ & $\mathbf{Z n}$ & $\mathbf{C u}$ & $\mathbf{F e}$ \\
\hline Group I ( $\mathrm{N}=25$ & $\begin{array}{c}235.3+ \\
85.37\end{array}$ & $\begin{array}{c}47.11 \pm 1 \\
3.7\end{array}$ & $\begin{array}{c}35.23 \pm 1 \\
6.33\end{array}$ & $\begin{array}{c}0.90 \pm 0 . \\
20\end{array}$ & $\begin{array}{c}11.78 \pm 2 \\
.33\end{array}$ & $\begin{array}{c}3.11 \pm 0 \\
.41\end{array}$ & $\begin{array}{l}0.0031 \pm 0 . \\
0012\end{array}$ & $\begin{array}{c}0.220 \pm 0 \\
019\end{array}$ & $\begin{array}{c}0.434 \pm 0 . \\
195\end{array}$ \\
\hline $\begin{array}{c}\text { Group II } \\
(\mathrm{N}=25) \text { Missed } \\
\text { abortion }\end{array}$ & $\begin{array}{c}177.62 * \pm \\
56.22\end{array}$ & $\begin{array}{c}42.68 \pm 8 . \\
98\end{array}$ & $\begin{array}{c}36.71 \pm 1 \\
6.5\end{array}$ & $\begin{array}{c}1.04 \pm 0 \\
25\end{array}$ & $\begin{array}{c}9.73+1 . \\
66^{*}\end{array}$ & $\begin{array}{c}3.21 \pm 0 \\
.50\end{array}$ & $\begin{array}{c}0.0029 \pm 0 . \\
0004\end{array}$ & $\begin{array}{c}0.222+0 \\
019\end{array}$ & $\begin{array}{c}0.460 \pm 0 . \\
178\end{array}$ \\
\hline $\begin{array}{c}\text { Group III } \\
(\mathrm{N}=12) \text { Ectopic } \\
\text { Pregnancy }\end{array}$ & $\begin{array}{c}102.4 * \pm 2 \\
4.50\end{array}$ & $\begin{array}{c}36.90 \pm^{*} \\
7.144\end{array}$ & $\begin{array}{c}14.15^{*} \pm \\
4.49\end{array}$ & $\begin{array}{c}0.99 \pm 0 . \\
24\end{array}$ & $\begin{array}{c}9.27 \pm 2 \\
18^{*}\end{array}$ & $\begin{array}{c}2.80 \pm 0 \\
.77\end{array}$ & $\begin{array}{c}0.0032 \pm 0 . \\
0008\end{array}$ & $\begin{array}{c}0.342 * \pm \\
0.063\end{array}$ & $\begin{array}{c}0.209^{*} \pm \\
0.040\end{array}$ \\
\hline $\begin{array}{l}\text { Group IV } \\
(\mathrm{N}=12) \text { Molar } \\
\text { Pregnancy }\end{array}$ & $\begin{array}{c}180.0 * \pm 4 \\
1.54\end{array}$ & $\begin{array}{c}31.78+ \pm^{*} \\
11.43\end{array}$ & $\begin{array}{c}12.65^{*} \pm \\
5.39\end{array}$ & $\begin{array}{c}1.096 * \pm \\
0.28\end{array}$ & $\begin{array}{c}9.87 \pm 1 \\
68^{*}\end{array}$ & $\begin{array}{c}2.67 \pm * \\
0.424\end{array}$ & $\begin{array}{l}0.003 \pm \\
0.0008\end{array}$ & $\begin{array}{c}0.395^{*} \pm \\
0.046\end{array}$ & $\begin{array}{c}0.223 * \pm \\
0.016\end{array}$ \\
\hline
\end{tabular}


* $\mathrm{P}<0.05$ compared with normal pregnancy.

Table 3: Correlation between Serum Paraoxonase Activity with $\mathrm{CP}, \mathrm{ALP}, \mathrm{Ca}, \mathrm{PO}_{4}{ }^{-3}$ and Creat. (Coefficient of Correlation/Significance r/p)

\begin{tabular}{|cccc|}
\hline Parameters & Missed Preg. & Ectopic Preg. & Molar Preg. \\
$\mathrm{CP}$ & $-0.138 / 0.512$ & $-0.425 / 0.043^{*}$ & $0.587 / 0.005^{*}$ \\
$\mathrm{ALP}$ & $-0.05 / 0.813$ & $-0.074 / 0.777$ & $+0.132 / 0.569$ \\
$\mathrm{Ca}$ & $0.068 / 0.746$ & $-0.154 / 0.555$ & $-0.29 / 0.201$ \\
$\mathrm{PO}_{4}^{-3}$ & $-0.18 / 0.389$ & $-0.379 / 0.133$ & $-0.281 / 0.217$ \\
$\mathrm{Creat}$. & $-0.463 / 0.020^{*}$ & $0.09 / 0.732$ & $0.422 / 0.057$ \\
$\mathrm{Zn}$ & $-0.294 / 0.153$ & $0.279 / 0.279$ & $-0.309 / 0.172$ \\
$\mathrm{Cu}$ & $0.121 / 0.564$ & $0.535 / 0.027 *$ & $-0.53 / 0.013^{*}$ \\
$\mathrm{Fe}$ & $-0.183 / 0.382$ & $-0.346 / 0.174$ & $-0.108 / 0.642$ \\
\hline
\end{tabular}

$* \mathrm{P}<0.05$ significant 